\title{
An appendage abnormality in the first left pereiopod of red swamp crayfish (Procambarus clarkii) reared in the laboratory conditions
}

\section{Laboratuvar koşullarında yetiştirilen kırmızı bataklık kerevitinin (Procambarus clarkiii) ilk sol yürüme bacağında bir uzantı anormalliği}

\author{
Onur Karadal \\ Department of Aquaculture, Faculty of Fisheries, İzmir Kâtip Çelebi University, 35620, Çiğli, İzmir, Turkey \\ (D) https://orcid.org/0000-0002-6241-5039

Abstract: Red swamp crayfish (Procambarus clarkii) is the most cultivated crayfish species in the world that has commercial importance for both aquaculture and aquarium industries. In this study, a case report of an appendage abnormality observed in the left cheliped of a female specimen (6.92 $\mathrm{g}$ ) reared under laboratory conditions is presented. It has been determined that the specimen has two appendages in the left cheliped root. Of these appendages, the right one $(1.27 \mathrm{~cm})$ ends in a blunt. On the left $(1.06 \mathrm{~cm})$, a spiny structure similar to that of the fourth and fifth walking legs was observed. Keywords: Cambaridae, external outgrowths, walking legs, cheliped, dactyl

Öz: Kırmızı bataklık kereviti (Procambarus clarkii), hem su ürünleri yetiştiriciliği hem de akvaryum sektörleri için ticari öneme sahip olan ve dünyada en fazla üretimi yapılan kerevit türüdür. Bu çalışmada, laboratuvar koşullarında yetiştirilen bir dişi bireyin $(6,92 \mathrm{~g})$ sol kıskacında gözlemlenen ekstremite anormalliği hakkında vaka takdimi sunulmuştur. Bireyin sol kıskaç kökünde iki uzantı oluştuğu tespit edilmiştir. Bu uzantılardan sağdaki (1,27 cm) küt bir şekilde sonlanmıştır. Soldakinde $(1,06 \mathrm{~cm})$ ise, dördüncü ve beşinci yürüme bacaklarındakine benzer dikenli bir yapı görülmüştür.

Anahtar kelimeler: Cambaridae, dış çıkıntılar, yürüme bacakları, kıskaç, daktil

\section{INTRODUCTION}

Red swamp crayfish (Procambarus clarkii) is a highly resistant and tolerant freshwater species that may dwell a widespread of wetlands, marsh areas, stagnant rivers, and lakes. The crayfish is originated from the north-eastern region of Mexico and the Louisiana, United States. This species is the most cultured crayfish in the world (FAO, 2018) and it is valuable for both aquaculture and aquarium industries. The crayfish can tolerant extreme conditions, such as oxygen and temperature alterations, water pollution, and drought (Barbaresi and Gherardi, 2000; Cruz and Rebelo, 2007). This factor lead an importance in selectivity of this species in aquaculture. Negatively, invasiveness has been informed from North and South America, Europe, Asia, and Africa (GISD, 2015). In Turkey, the species introduced to aquarium sector in the last quarter of 2000's. Currently, there is no qualified red swamp crayfish cultivation in Turkey, but this crayfish exposed as one of the most common and popular species in the aquarium sector of Turkey.

The species has a dominant body colour as typically red, reddish brown or orange (Gherardi, 2011). It grows rapidly and adults can reach up to $15 \mathrm{~cm}$ in length, though optimum body length is $12 \mathrm{~cm}$ (Henttonen and Huner, 1999; Loureiro et al., 2015). Body of this species is mainly separated as cephalothorax and abdomen (Hobbs, 1974). As all the crustacean decapods, red swamp crayfish have five pairs of walking legs (pereiopods) beneath their cephalothorax. The first pairs of pereiopods are specialized as big claws called cheliped. The second and third pairs of pereiopods have small pincers which act as hold and handle. The fourth and fifth pairs have no structure like claw or pincer, whilst these pereiopods have spines for walking and stabilizing. Different types of appendage abnormalities have been reported in previous studies (Nakatani et al., 1992, 1997, 1998; Murayama et al., 1994; Nakatani, 1996; Nakatani and Kitahara, 1999) on this species. In these studies, generally extra and lateral outgrowths on the chelipeds or other appendages have been reported.

In this case, an abnormality was observed in the left cheliped, which has branched structure of a specimen of red swamp crayfish and this situation was reported.

\section{MATERIALS AND METHODS}

\section{Laboratory conditions and rearing system}

The case was observed in Invertebrates Culture Laboratory, Faculty of Fisheries, İzmir Kâtip Çelebi University, 
Çiğli, İzmir, Turkey. Red swamp crayfish (Procambarus clarkii) were obtained from a commercial facility and reared in the laboratory conditions. The crayfish were stocked into two recirculating freshwater sump systems $(270 \mathrm{~L}$ in each) and fed twice daily with commercial bottom feed (Artakua $\AA$, Tire, İzmir, Turkey), routinely. The temperature in the systems was held at $25-26{ }^{\circ} \mathrm{C}$ with external heaters (Hydor ETH 300). Dissolved oxygen and $\mathrm{pH}$ were measured daily with $\mathrm{AZ}$ 84051 Combo Water Meter and their range were recorded as 8.70-9.50 ppm and 7.30-7.80, respectively.

\section{General features of the crayfish specimen}

Among the crayfish in the sump systems, a female specimen (Figure 1) was attentional. An appendage abnormality in the left cheliped was observed, whilst no anomaly was found in its other pereiopods (walking legs) and pleopods (swimming legs). Then, the female was examined closely and recorded some body measurements (Table 1).

Specimen was weighed with an electronic balance (Kern PCB 2500-2, precision of \pm 0.01 ) and total length $(T L)$, carapace length $(\mathrm{CL})$, and carapace width $(\mathrm{CW})$ were measured with a digimatic caliper.

Table 1. Some body measurements of the female specimen

\begin{tabular}{lc}
\hline & Measurement \\
\hline Weight $(\mathrm{g})$ & 6.92 \\
Total length $(\mathrm{cm})$ & 6.50 \\
Carapace length $(\mathrm{cm})$ & 2.42 \\
Carapace width $(\mathrm{cm})$ & 1.44 \\
\hline
\end{tabular}

\section{RESULTS}

Details and measurements of abnormal appendage were shown in Figure 2. It has been observed that the base of the appendage $(0.65 \mathrm{~cm})$ emerged from the root of left cheliped and it branched elongated. The appendage has two branches: a taller in the right $(1.27 \mathrm{~cm})$ and a shorter-spiny in the left $(1.06 \mathrm{~cm})$. Taller branch has a one joint and two parts $(0.70$ and $0.57 \mathrm{~cm})$. Shorter branch has a spine at its end $(0.19 \mathrm{~cm})$.

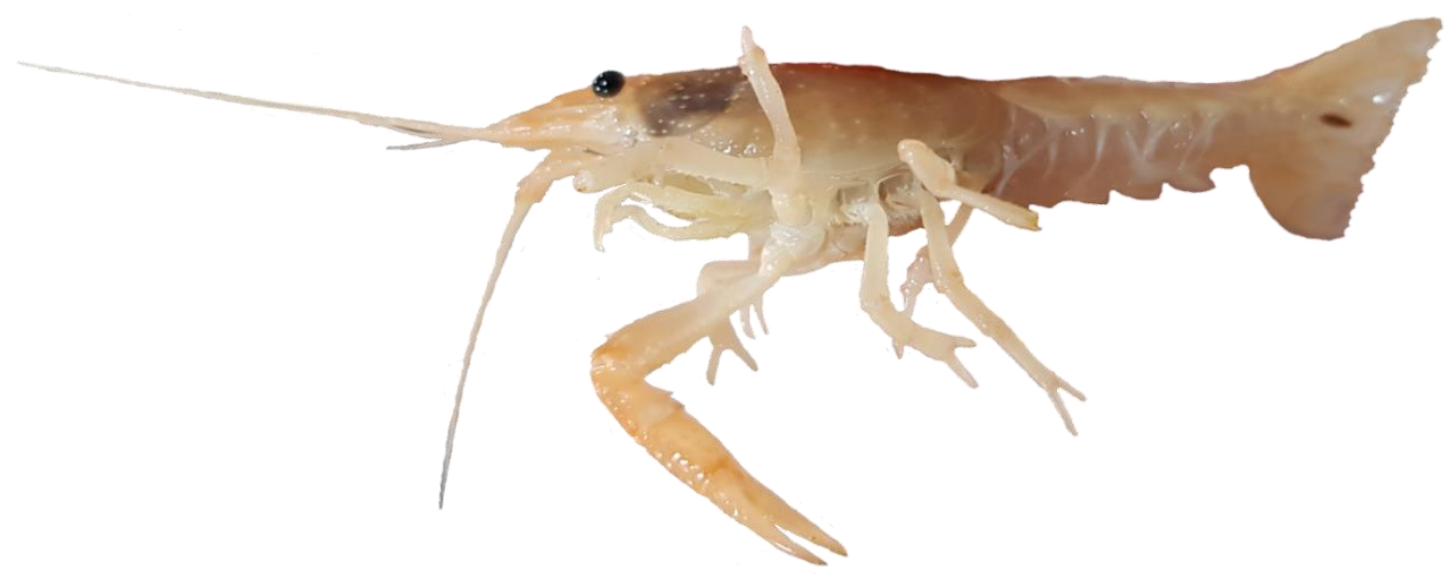

Figure 1. General view of the female red swamp crayfish (Procambarus clarkii) specimen

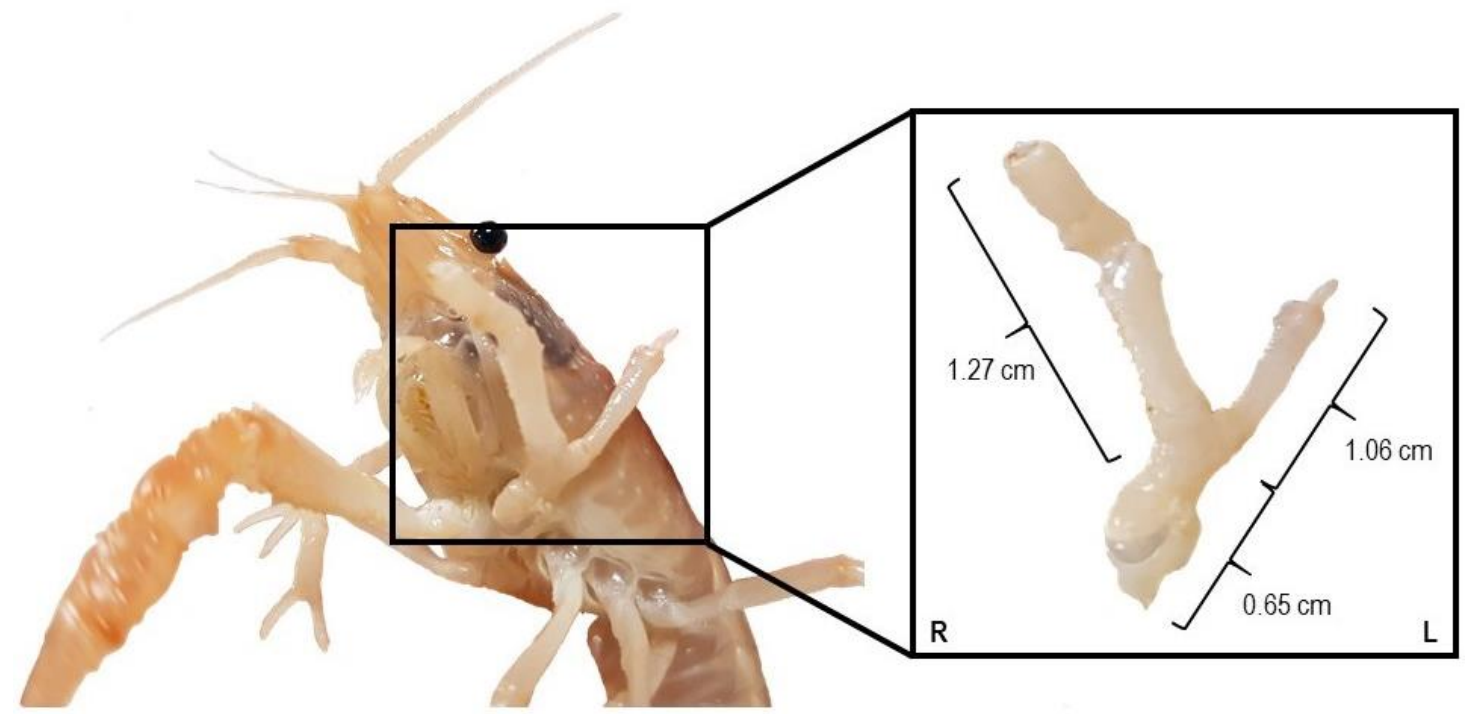

Figure 2. Detailed view and length measurements of the abnormal appendage onto the female red swamp crayfish (from dorsal view R: right, L: left) 


\section{DISCUSSION}

The pereiopods are five in number in the infraorder Astacidea and the first three pairs have claws (Crandall and Buhay, 2008). Though, in this case, the left cheliped of female specimen has an abnormality and no claw was existing. In previous studies, the authors reported lateral outgrowths from the chelipeds in naturally captured red swamp crayfish (Nakatani et al., 1992, 1997) and laboratory studies have resulted that this type of occurrence could be induced in this crayfish species by wounded healing (Murayama et al., 1994; Nakatani, 1996; Nakatani et al., 1998; Nakatani and Kitahara, 1999). In contrast, in this case, no claw has appeared, while two branched structures were recorded. Also, Nakatani et al. (1997) found an outcrop at the propodus of the left third pereiopod and they stated that a dactylus was appeared at the next moult. Abnormal branched appendage existed from the basis of the left cheliped and no propodus and dactylus were formed in the current case. Rasheed et al. (2014) reported an existing propodus and dactylus in the fifth

\section{REFERENCES}

Barbaresi, S. \& Gherardi, F. (2000). The invasion of the alien crayfish Procambarus clarkii in Europe, with particular reference to Italy. Biological Invasions, 2(3), 259-264. DOI: 10.1023/A:1010009701606

Crandall, K.A. \& Buhay, J.E. (2008). Global diversity of crayfish (Astacidae, Cambaridae, and Parastacidae-Decapoda) in freshwater. Hydrobiologia, 595, 295-301. DOI: 10.1007/978-1-4020-8259-7_32

Cruz, M.J. \& Rebelo, R. (2007). Colonization of freshwater habitats by an introduced crayfish, Procambarus clarkii, in Southwest lberian Peninsula. Hydrobiologia, 575(1), 191-201.

DOI: $10.1007 /$ s10750-006-0376-9

FAO. (2018). Food and Agriculture Organization. AQUASTAT database. Retrieved from http://www.fao.org/nr/water/aquastat/main/index.stm (27.05.2020).

Gherardi, F. (2011). Crayfish. In: D. Simberloffand \& M. Rejmánek (Eds.), Encyclopedia of Biological Invasions (pp. 129-135). Berkeley, University of California Press.

GISD. (2015). Global Invasive Species Database. Species profile Procambarus clarkii. Retrieved from http://www.iucngisd.org/gisd/species.php?sc=608 (03.06.2020)

Henttonen, P. \& Huner, J.V. (1999). The introduction of alien species of crayfish in Europe: A historical introduction. In: F. Gherardi, \& D.M. Holdich (Eds.), Crustacean Issues 11: Crayfish in Europe as Alien Species (How to Make the Best of a Bad Situation?) (pp. 13-22). A.A. Balkema, Rotterdam, Netherlands.

Hobbs, H.H. (1974). Synopsis of the families and genera of crayfishes (Crustacea, Decapoda). Smithsonian Contributions to Zoology, 164, 132. DOI: $10.5479 /$ si.00810282.164

Juanes, F. \& Smith, L.D. (1995). The ecological consequences of limb damage and loss in decapod crustaceans: A review and prospectus. Journal of Experimental Marine Biology and Ecology, 193(1-2), 197-223. DOI: 10.1016/0022-0981(95)00118-2

Loureiro, T.G., Anastácio, P.M.S.G., Araujo, P.B., Souty-Grosset, C. \& Almerão, M.P. (2015). Red swamp crayfish: biology, ecology and pereiopod (shaped like paddle) of blue swimming crab (Portunus pelagicus) and the authors declared that the cause of abnormality is an accident during moulting or regenerating.

In previous research, it has been stated that these abnormalities are the results of failing in healing of the wounds (Shelton et al., 1981; Nakatani et al., 1992; Nakatani, 1996; Mariappan et al., 2000). Nakatani et al. (1998) declared that various mechanisms led to cause of these kinds of outgrowths, extra claws or dactyls. The outgrowth may be related to the shape of the wound or to the period of the moulting during the moment of wounding. Failure in healing of wounds in some cases could explain with occurring of lateral outgrowths (Shelton et al., 1981; Murayama et al., 1994). Additionally, these abnormalities would result some disadvantages, such as to reduce the feeding efficiency, mating failure, and more vulnerable to external attacks (Juanes and Smith, 1995). Further studies are needed to research the causes and results of these abnormalities in detail.

invasion-an overview. Nauplius, 23(1), 1-19 DOI: 10.1590/S0104-64972014002214

Mariappan, P., Balasundaram, C. \& Schmitz, B. (2000). Decapod crustacean chelipeds: An overview. Journal of Biosciences, 25(3), 301-313. DOI: $10.1007 / \mathrm{BF} 02703939$

Murayama, O., Nakatani, I. \& Nishita, M. (1994). Induction of lateral outgrowths on the chela of the crayfish, Procambarus clarkii (Girard). Crustacean Research, 23, 69-73. DOl: 10.18353/crustacea.23.0_69

Nakatani, I., Yamauchi, K. \& Murayama, O. (1992). Abnormalities found in the chela of the crayfish, Procambarus clarkii (Girard). Researches on Crustacea, 21, 207-209. DOI: 10.18353/rcustacea.21.0_207

Nakatani, I. (1996). Morphology of lateral outgrowths induced on chelipeds of the crayfish Procambarus clarkii (Girard). Crustacean Research, 25, 142-150. DOI: 10.18353/crustacea.25.0_142

Nakatani, I., Okada, Y. \& Yamaguchi, T. (1997). An extra claw on the first and on the third cheliped of the crayfish, Procambarus clarkii (Decapoda, Cambaridae). Crustaceana, 70(7), 788-798. DOI: 10.1163/156854097X00230

Nakatani, I., Okada, Y. \& Kitahara, T. (1998). Induction of extra claws on the chelipeds of a crayfish, Procambarus clarkii. Biological Bulletin, 195(1), 52-59. DOI: $10.2307 / 1542775$

Nakatani, I. \& Kitahara, T. (1999). Induction of outgrowths at wounds on the cheliped of Procambarus clarkii (Decapoda: Cambaridae). Journal of Crustacean Biology, 19(1), 1-7. DOI: 10.2307/1549540

Rasheed, S., Mustaquim, J. \& Khanam, S. (2014). Some external abnormalities found in edible crabs, Portunus pelagicus and $P$. sanguinolentus, of Pakistan. Pakistan Journal of Zoology, 46(2), 541548.

Shelton, P.M.J., Truby, P.R. \& Shelton, R.G.J. (1981). Naturally occurring abnormalities (Bruchdreifachbildungen) in the chelae of three species of Crustacea (Decapoda) and a possible explanation. Journal of Embryology and Experimental Morphology, 63, 285-304. 